\title{
Award-winning papers in 2011
}

Papers published in Ground Improvement are eligible for awards from the Institution of Civil Engineers. Papers from any of the ICE journals can be nominated for several awards. In addition, each journal has awards dedicated to their specific subject area.

On Friday 12 October 2012, ICE President Richard Coackley presented awards to the following papers published in Ground Improvement in 2011 The editorial panel nominated their best papers and an awards committee chaired by Barry Clarke allocated the awards.

\section{Telford Premium Prize}

The Telford Premium Prize, presented for the best paper on ground improvement, was awarded to Bin Ahmad et al. (2011).

\section{Abstract}

The results of shear box and consolidation tests on electrokineticallytreated tropical residual soil are presented. Injections of selected chemicals (calcium chloride, aluminium chloride and phosphoric acid) into the soil samples at the anodes or cathodes were carried out in cylindrical electrokinetic cells via applications of $30 \mathrm{~V}$ DC electrical potential for $168 \mathrm{~h}$. Four different open-anode and open-cathode electrokinetic systems utilising different anolytes and catholytes were employed to treat the soil samples. The shear resistances of the treated soil utilising distilled water as the anolyte and $1.0 \mathrm{~mol} / \mathrm{l}$ phosphoric acid as the catholyte was enhanced, whereas the treated soil near the cathode showed significant reduction in compressibility. Soil treated utilising the other chemicals showed no significant changes.

\section{Bill Curtin Medal}

The Bill Curtin Medal, presented to the best paper describing innovative design in civil engineering, was awarded to Cristelo et al. (2011).

\section{Abstract}

This research studied the use of alkaline activation of fly ash, as a silica and alumina amorphous source, to improve soft soils. A laboratory programme

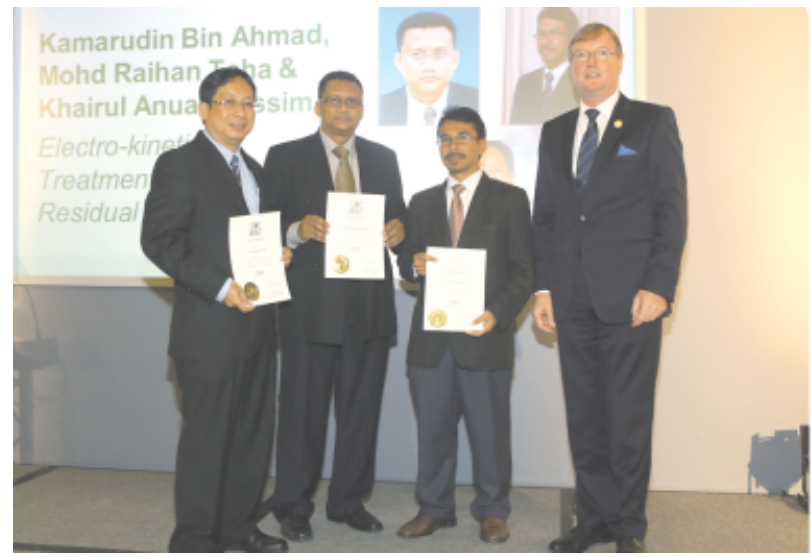

ICE President Richard Coackley presents the Telford Premium Prize to Kamarudin Bin Ahmad, Mohd. Raihan Taha and Khairul Anuar Kassim

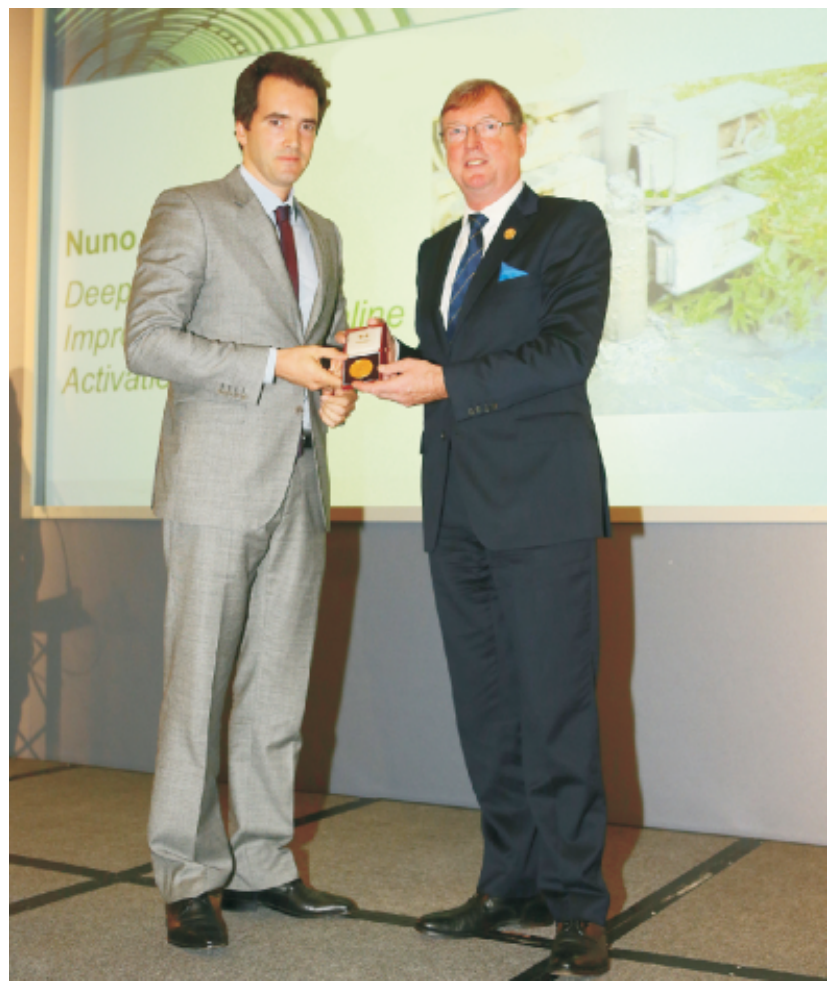

ICE President Richard Coackley presents the Bill Curtin Medal to Nuno Cristelo, Stephanie Glendinning and Amândio Teixeira Pinto

- including tests to study strength and deformability development, alternative curing methods, the effect of the different components of the grout, effect of raising initial temperature and comparison with a cement grout - was carried out. Laboratory tests revealed that the use of fly ash and alkaline activator resulted in a soil strength improvement up to 11.4, 16.7 and $43.4 \mathrm{MPa}$, at 28, 90 and 365 days curing, respectively. The most effective combinations obtained in the laboratory were chosen for the field application with jet grouting. The grout performed adequately to pass standard engineering specifications for soil mixing, achieving up to $26.4 \mathrm{MPa}$ at 90 days curing. The main conclusion is the potential of alkaline activation for soil improvement, and therefore this research has created a basis for further studies.

\section{REFERENCES}

Ahmad KB, Taha MR and Kassim KA (2011) Electrokinetic treatment on a tropical residual soil. Proceedings of the Institution of Civil Engineers - Ground Improvement 164(1): 3-13, http://dx.doi.org/10.1680/grim.800025.

Cristelo N, Glendinning S and Teixeira Pinto A (2011) Deep soft soil improvement by alkaline activation. Proceedings of the Institution of Civil Engineers - Ground Improvement 164(2): 73-82, http://dx.doi.org/10.1680/grim.900032. 